\title{
UKRAINIAN CULTURE IN THE INTERNATIONAL ARENA: STRATEGIES OF MODERN CULTURAL DIPLOMACY
}

\section{Kostyrya Inna}

\section{INTRODUCTION}

Revealing the concept of "culture", Cicero introduced the concept of "cultura animi" - "the soul cultivation", applying the agricultural metaphor to the development of the soul as a philosophical category. He considered culture to be a way of overcoming the various barbarisms' displays and a tool for turning a person into a worthy citizen. Culture is a combination of human knowledge, beliefs and behaviours that we adopt and then pass on to future generations. Culture is a key factor in socialization that regulates different areas of human interaction. Therefore, there is a diversity of its roles in society.

Today, international relations are characterized by a variety of cooperation, with culture playing an extremely important role in. There has significantly increased the cultural dialogue influence on interstate contacts, which is a decisive factor in modifying the relations of the parties and shaping the image of the country and far beyond it. It is difficult to overestimate the role of culture in the favourable climate of the international cooperation, since cultural cooperation creates the preconditions for developing the interaction of countries in all spheres of public life. In today's international relations, there is a huge potential for "cultural appeal" that has never been used before. That is why we see an active involvement of the cultural sector in the foreign policy of states and international organizations. There is also a growing interest on the part of European researchers and politicians to study and interpret soft power, public diplomacy, and cultural diplomacy.

At the same time, cultural diplomacy as a policy should not be confined to the tasks of the sphere of foreign policy alone. Reacting also to the cultural demands of society, it participates in its formation, reflecting its own experience and planning for the future. Cultural diplomacy, in fact, can and should be an integral part of the cultural policy of the state.

In times of conflict and tension, art usually goes into the background. However, creativity is inherent in people, both in peace and in times of conflict. After major conflicts and catastrophes, cultural heritage becomes a symbol and a tool for rebuilding society. 


\section{"Culture" - "Cultural Diplomacy": Understanding the Concept}

It is difficult to imagine international politics without such a significant component as culture. It has always played and will play a leading role in this process. Since culture is widely recognized to be factor influencing a nation to reveal its identity to the world, to present its heritage, so cultural diplomacy is undoubtedly to be a powerful instrument of cultural policy and the state's international relations. Therefore, it is impossible to imagine interstate dialogue without addressing to cultural diplomacy. The term "cultural diplomacy" is not new. Researchers prove that it appeared in the scientific circulation in 1930s. The American scholar Milton Cummings offered one of the first scientific definitions of the term "cultural diplomacy". According to him it is the exchange of ideas, information, values, systems, traditions, beliefs and other aspects of culture in order to foster mutual understanding ${ }^{1}$.

Contemporary researchers consider cultural diplomacy in the context of promoting the state's interests at the international level by means of culture and art. Thus, Ye. Astakhov states that inter-civilization dialogue cannot do without cultural diplomacy, but can do without the power export of political, ideological and religious postulates ${ }^{2}$.

In 1967 there was given another definition of "cultural policy" at the UNESCO Round Table in Monaco. In the report "Culture Policy Preliminary Considerations", culture policy was to mean a set of operational principles, administrative and financial activities and procedures that provide the basis for government action in the field of culture. In this context, the implementation of cultural policy is the whole sum of conscious and deliberate actions (or lack of action) in society aimed at achieving certain cultural goals through the optimal use of all the physical and spiritual resources currently possessed by society ${ }^{3}$. This definition has led many countries to shape their cultural policies at the national level.

In its turn, the authors of the study "Culture and cultural diplomacy in a comparative study of the Canadian and Chinese case" note that cultural diplomacy is both a "new" and an "old" term in the world of diplomacy ${ }^{4}$. On the one hand, it can be explained with the first examples of cultural

1 Monko T.S. (2017) Mizhnarodni vidnosyny yak skladova kulturnoi polityky Ukrainy na suchasnomu etapi [International relations as a part of cultural policy of Ukraine at the present stage]. Visnyk Natsionalnoi akademii kerivnykh kadriv kultury $i$ mystetstv [National Academy of Managerial Staff of Culture and Arts Herald], no. 2, pp. 52-55.

${ }^{2}$ Ibid.

${ }^{3}$ UNESCO (1969) Cultural Policy: A Preliminary Study. Round-table Meeting on Cultural Policies (Monte Carlo, Monaco, 1967), UNESCO.

${ }^{4} \mathrm{Hu}$ Yue (2011) Culture and Cultural Diplomacy: A Comparative Study of a Canadian and Chinese Case (PhD Thesis), University of Regina, Canada. 
diplomacy been found in the relations between states in the II-III millennia BC. On the other hand, as an independent phenomenon it has been started exploring only after World War II ${ }^{5}$.

At the same time, when it comes to purposeful practice of using "culture" to achieve foreign policy goals, such researchers as K. Hamilton and R. Langhorne offer an appeal to the activities of medieval Byzantine missionaries who spread not only religious doctrines, but also views of the world at large, certain ideas, beliefs, and orders ${ }^{67}$.

Modern history considers France to be the first state to practice the purposeful use of cultural diplomacy. Erik Pajtinka in his research notes that "as the very first institution of this kind may be considered Alliance Française founded on the initiative of a French diplomat P. Cambon in Parisin 1883 that opened its first foreign branch, officially called comitélocal, a year later in Barcelona, Spain. It should be added that Alliance Française, whose activities have focused primarily on supporting the promotion of French language abroad, has been legally a nongovernmental organisation (NGO) and not a diplomatic body of state (although in practice its activities have been usually closely coordinated with and/or sponsored by the French Foreign Ministry)",

In systematic studies on cultural diplomacy since the Second World War, researchers have defined cultural diplomacy as "achieving foreign policy goals through cultural communication or other cultural-related diplomatic activities", $"$.

In addition, the relationship between cultural and public diplomacy is not fully understood. Today, cultural diplomacy is most often perceived as a

5 Dubov D., Dubova S. (2017) Polityka kulturnoi dyplomatii yak mekhanizm realizatsii stratehichnykh komunikatsii derzhavy [The policy of cultural diplomacy as a mechanism for implementing strategic communications of the state]. Naukovi pratsi Natsionalnoi biblioteky Ukrainy imeni V. I. Vernadskoho [Academic Papers of Vernadsky National Library of Ukraine], iss. 46, pp. 62-73.

${ }^{6}$ Ibid.

${ }^{7}$ Hamilton K., Langhorne R. (2010) The Practice of Diplomacy: Its Evolution, Theory and Administration. New York: Routledge.

${ }^{8}$ Pajtinka E. (2014) Cultural diplomacy in the theory and practice of contemporary international relations. Politické vedy [Political Sciences] (electronic journal), no. 4, pp. 95-108. Retrieved from: http://www.politickevedy.fpvmv.umb.sk /archivvydani/2014/4-2014/ (accessed 4 December 2020).

$9 \mathrm{Hu}$ Yue (2011) Culture and Cultural Diplomacy: A Comparative Study of a Canadian and Chinese Case (PhD Thesis), University of Regina, Canada.

10 Dubov D., Dubova S. (2017) Polityka kulturnoi dyplomatii yak mekhanizm realizatsii stratehichnykh komunikatsii derzhavy [The policy of cultural diplomacy as a mechanism for implementing strategic communications of the state]. Naukovi pratsi Natsionalnoi biblioteky Ukrainy imeni V. I. Vernadskoho [Academic Papers of Vernadsky National Library of Ukraine], iss. 46, pp. 62-73. 
component of public diplomacy (including such practices in Ukraine. However, researcher in the field of cultural diplomacy E. Pajtinka emphasizes that the concept of "public diplomacy" is still broader than the concept of "cultural diplomacy", since public diplomacy encompasses a number of activities that do not fall under the responsibility of cultural diplomacy ${ }^{11}$.

Ukrainian researcher Oksana Rozumna considers "cultural diplomacy" as a set of techniques, methods and practical measures developed and implemented by foreign relations bodies and/or other authorized state bodies that support the diplomatic activity of the state by broadcasting samples of national culture abroad ${ }^{12}$.

Jerzy Onuch, an ex-director of the Polish Institute in Ukraine and Polish Cultural Institute in New York, states that diplomacy is part of the culture, which is often forgotten by professional diplomats, and even more often by politicians. Cultural diplomacy is a long-standing activity; a tool of public policy designed for the long term, and therefore should not be a specific tool of political orientation that prevails at this moment. Cultural diplomacy is sailing the image of the country by cultural means. Art provides sophistication and "gentleness" to political strategies, helps to maintain respect for the country, nation, individual as a society's representative $\mathrm{e}^{13,14}$.

"Cultural Diplomacy may best be described as a course of actions, which are based on and utilize the exchange of ideas, values, traditions and other aspects of culture or identity, whether to strengthen relationships, enhance social and cultural cooperation, promote national interests and beyond; Cultural diplomacy can be practiced by either the public sector, private sector or civil society" 15 .

${ }^{11}$ Pajtinka E. (2014) Cultural diplomacy in the theory and practice of contemporary international relations. Politické vedy [Political Sciences] (electronic journal), no. 4, pp. 95-108. Retrieved from: http://www.politickevedy.fpvmv.umb.sk/ archiv-vydani/2014/42014/ (accessed 4 December 2020).

12 Rozumna O. P. (2016) Kulturna dyplomatiya Ukrayiny: stan, problemy, perspektyvy: Analitychna dopovid [Cultural diplomacy of Ukraine: state, problems, prospects: Analytical report]. Kyiv: National Institute for Strategic Studies. Retrieved from: https://niss.gov.ua/sites/ default/files/2016-09/kultu_dypl-26841.pdf (accessed 4 December 2020).

${ }^{13}$ Onuch J. (2016) Kulturna dyplomatiia, abo Vmist tsukru v tsukri [Cultural diplomacy, or Sugar content in sugar]. Ukrainskyi tyzhden [Ukrainian Week], no. 16(440), p. 50.

${ }^{14}$ Rzhevska N. F. (2018) Kulturna dyplomatiia Ukrainy: suchasnyi stan ta perspektyvy. Mizhnarodni vidnosyny. Seriia "Politychni nauky" [International Relations, part "Political Sciences"] (electronic journal), no. 18-19. Retrieved from: http://journals.iir.kiev.ua/index.php/ pol_n/article/view/3377/3055 (accessed 4 December 2020).

${ }^{15}$ Institute for Cultural Diplomacy (n.d.) What is Cultural Diplomacy? What is Soft Power? Retrieved from: http://www.culturaldiplomacy.org/index.php?en_cultural diplomacy (accessed 4 December 2020). 
Traditionally, there are three key characteristics of cultural diplomacy distinguished: breadth (coverage of the events involved), non-violence and invisibility. However, today there is the question remaining unsolved for researchers: to what extent is the country's culture related to cultural diplomacy and what is the effect of cultural diplomacy in general.

\section{Cultural Diplomacy: the Experience of Central and Eastern Europe}

The realities of the European society have such specific characteristics of the cultural field as: the multifaceted contribution of other cultures and civilizations (language, economics, history, sciences, philosophy and literature, music, daily life, etc.); localization of cultures (regions of Europe as historical, cultural, geographical or economic entities); linguistic and ethno-cultural pluralism as a consequence of the historical formation of the European nations; deepening the current presence of other cultures in European countries; finally, the cultural diversity of the representative European Diaspora. These realities require appropriate decisions, strategies and programs in the field of intercultural cooperation, both at pan-European and national levels.

Therefore, for today's European society, it is crucial to solve a number of theoretical and practical problems in the implementation of cultural diplomacy ${ }^{16}$ :

1) development of programs and strategies of the intercultural cooperation in the conditions of globalization and formation of the information society;

2) a balance between pan-European identity politics and adherence to the principles of multiculturalism, dialogue between cultures, civilizations and religions;

3) overcoming cultural and linguistic barriers;

4) the formation of a mechanism for the protection of the European cultural and linguistic space;

$5)$ ensuring the rights of national minorities.

The cultural diplomacy of Western countries was shaped by the imperial and colonial past of most of them. The countries of Central and Eastern Europe did not have colonies, but were the subject of many European treaties and pacts throughout their history ${ }^{17}$.

${ }^{16}$ Basenko Ya. (2013) Kulturna dyplomatiia v Yevropi [Cultural diplomacy in Europe]. Eminak, no. 1-4, pp. 53-57.

${ }^{17}$ Trofymenko M. V. (2017) Publichna dyplomatiia krain Tsentralnoi ta Skhidnoi Yevropy [Public diplomacy of Central and Eastern European Countries]. Visnyk Mariupolskoho derzhavnoho universytetu. Seriia: Istoriia. Politolohiia [Journal of Mariupol State Univeristy. Series: History. Political Studies], iss. 19, pp. 257-26. 
After the fall of communism, the countries of Central and Eastern Europe went through radical economic and political changes. The transition from centralized planning to a market economy, from an authoritarian one-party system to a pluralistic and democratic society was a real challenge for the countries of the region. These transformations have also affected changes in national identity and image of countries. In these processes, cultural diplomacy played a significant role.

The processes of institutionalization of cultural diplomacy in the countries of Central and Eastern Europe proceeded differently, but the creation of specific governmental organizations, departments and positions required the research and evaluation of the existing vision in the different target countries; developing communication policies, strategies and tactics to promote political and economic interests abroad; coordination of efforts of different organizations, etc ${ }^{18}$.

Cultural diplomacy has always been one of the most important components of foreign policy in many countries of Central and Eastern Europe. It is closely connected with the government of the country and the achievement of its foreign policy goals. Culture in this sense acts as a tool for achieving foreign policy goals and is thus politicized. Cultural relations relate to the development of cultural products such as literature, cinema, television, radio, art, science, music, as well as the study of the foreign languages. The ultimate goal is to familiarize the foreign public with the state, its people, culture and language, as well as create a favourable view of the country through its culture.

Hungarian Cultural Centres, Polish Institute, Estonian Institute, Latvian Institute, Bulgarian Cultural Institute, Czech Centres are the leading cultural institutions in Hungary, Poland, Estonia, Latvia, Bulgaria, Czech Republic. The main aim of the Estonian Institute, for example, is to disseminate information about Estonian society, culture and learning both in Estonia and abroad; introducing Estonian culture to other countries and promoting cultural communication between Estonia and other countries; support for the teaching of Estonian language and culture subjects at universities abroad, etc $^{19}$. The institutions and centres of Central and Eastern Europe are closely linked and dependent on the funding of their governments and ministries, unlike their Western European counterparts, such as the British Council or the Goethe Institute, which have greater independence and do not directly relate their governments. The cultural institutions and centres of the countries of Central and Eastern Europe are only in the most strategically

\footnotetext{
18 Ibid.

${ }^{19}$ Ibid.
} 
important countries due to the lack of funding, which prevents these countries from establishing cultural centres in many countries.

On 8 June 2016, "the EU High Representative and Vice-President Frederica Mogherini and Commissioner Navracsics put forward a proposal to develop the EU strategy to international cultural relations. The aim is to put cultural cooperation at the centre of the EU's diplomatic relations with countries around the world" 20 The strategy pointed out three main objectives $^{21}$ :

- unlocking the potential of culture and creativity for sustainable social and economic development; culture is a source of inclusive growth and job creation and the global trade in creative products has continued to expand in recent years, despite economic uncertainty;

- promoting peace and fighting radicalisation through intercultural dialogue; intercultural dialogue can build and promote understanding within and between societies. It helps to demonstrate the value of cultural diversity and human rights;

- strengthening cooperation on cultural heritage.

It is the EU that is responsible for developing innovative methods of cultural diplomacy, for cooperation in education and science, and for developing intercultural dialogue while distinguishing the following key tasks ${ }^{22}$ :

- to enhance the capacity of the Member States and the EU as a whole to harness the economic potential of the creative industry, namely to stimulate the development of a sustainable development model and to create favourable conditions for investment and jobs;

- to promote the development of cultural policy as a factor of peace and social and economic development in third countries, as well as a tool for preserving diversity and cultural pluralism;

- to make the EU a stronger global player in the international arena, to make more effective use of the historical levers of European soft power".

In March 2017, Florence hosted the first International G7 Culture Summit, during which there was signed a "Joint Declaration of the Ministers of Culture of G7 on the Occasion of the Meeting: Culture as an Instrument for Dialogue Among Peoples" ${ }^{23}$. This Declaration is a basic document that

${ }^{20}$ European Parliament (2017) Towards an EU strategy for international cultural relations (2016/2240(INI)). Retrieved from: https://www.europarl.europa.eu/doceo/ document/TA-8-2017-0303_EN.html (accessed 4 December 2020).

${ }^{21}$ Ibid.

${ }^{22}$ Ibid.

${ }^{23}$ Ministers of Culture of G7 (2017) Culture as an Instrument for Dialogue among Peoples: Joint Declaration of the Ministers of Culture of G7 on the Occasion of the Meeting (Florence, March 30, 2017). Retrieved from: http://www.g7.utoronto.ca/ culture/culture-2017-en.html (accessed 4 December 2020). 
consolidates the function of a certain instrument for establishing a dialogue between peoples capable of facilitating coordination on the protection of cultural heritage.

Such an active involvement of culture in international relations has led to a change in the concept of "culture", incorporating into it such elements as cultural security, cultural conflict, cultural war, and cultural diplomacy.

Moreover, the EU is currently developing several new initiatives within the framework of cultural diplomacy. The first is the creation of "creative hubs" of Europe in countries such as China and Brazil, the second concerns the introduction of the post of Special Representative for Cultural Exchange and Programs at each EU Delegation. The common vector is the expansion of cooperation between Member States in order to maximize European cultural diplomacy, the expansion of cooperation between cultural institutions and civil society ${ }^{24}$.

Therefore, most Central and Eastern European countries are relatively small, so competing for drawing attention, influence and impression making are very important processes for them. Limited financial and human resources aimed at forming national identities, policies and interests abroad seriously limit the realization of public diplomacy, especially because of been financed from the central budget. Consequently, the efforts of cultural diplomacy in Central and Eastern European countries focus on clearly defined countries, geopolitical and geographical positions. Countries in the region need to be very creative in order for their voice to be heard; they to try to identify niches in foreign policy areas that they might take up.

Thus, the experience of the EU Member States shows that today it is important to develop new areas of cultural dialogue and cooperation, both within the EU and internationally, for both governmental and nongovernmental programs. Practice shows that the development of cultural diplomacy in the EU countries significantly increases the effectiveness of foreign policy, adds prestige to states, national governments, reduces the influence of negative stereotypes, and strengthens the state's authority ${ }^{25}$.

${ }^{24}$ Rzhevska N. F. (2018) Kulturna dyplomatiia Ukrainy: suchasnyi stan ta perspektyvy. Mizhnarodni vidnosyny. Seriia "Politychni nauky" [International Relations, part "Political Sciences"] (electronic journal), no. 18-19. Retrieved from: http://journals.iir.kiev.ua/ index.php/pol_n/article/view/3377/3055 (accessed 4 December 2020).

${ }^{25}$ Lutsyshyn H., Honcharuk A. (2017) Osoblyvosti rozvytku kulturnoi dyplomatii Ukrainy $\mathrm{v}$ suchasnykh umovakh [Peculiarities of the development of Ukrainian cultural diplomacy in modern conditions]. Humanitarian Vision, vol. 3, no. 1, pp. 25-30. 


\section{Main Strategies for the Cultural Diplomacy of Ukraine}

All states that have relied on public and cultural diplomacy are talking about themselves, their own vision of the world and their place among others, in short, their values. There are countries for which culture and what follows it - cultural diplomacy - are a matter of major national importance. Ukraine is facing this task as well. Despite significant changes in the social life of Ukraine and the world, outdated perceptions of culture still prevail in the system of public administration. Thus, Ukrainian humanitarian and cultural policies have traditionally been reduced to relatively autonomous and poorly coordinated activities by various agencies related to the protection of cultural heritage, artistic activity, printing, library and archives. Ukraine needs a new, more integrated model of cultural and informational space, including managerial one. Within this space, the activities of the relevant bodies will focus not on the "current management" of solving numerous social and cultural problems and troubles, but on the implementation of the policy of the cultural sphere and its economic efficiency's strategic development, which is characteristic of most European countries.

Some steps are being taken today in Ukraine to support public and cultural diplomacy at the national level.

In Ukraine, cultural diplomacy is carried out at the state level by the Ministry of Culture and Tourism, the Ministry of Foreign Affairs, the Ministry of Education and Science, the State Committee on Television and Radio Broadcasting of Ukraine, non-governmental public organizations and individuals ${ }^{26}$.

However, the development of cultural diplomacy of Ukraine is not systematic. In early 2000s, there were created some state structures, the task of which was to develop cultural diplomacy. In particular, the State Agency for the Promotion of Culture of Ukraine was established in 2009, but its work has remained inconspicuous at the domestic level, not to mention international promotion.

Discussions about the importance of establishing Ukrainian institutions (Shevchenko institutes, Ukrainian cultural centres) in the leading European states have been under discussion for several years, but all these issues are at the project level. In 2015, it was decided to establish the Ukrainian Institute as a state institution with the functions of cultural diplomacy. According to the Concept proposed Ministry of Culture of Ukraine, the Ukrainian Institute should act as a network-type non-governmental organization. However, this idea has raised a lot of questions and discussions within the Ukrainian

${ }^{26}$ Ibid. 
society regarding the subordination of the newly established institution, the priority of its tasks, the opening of its representative offices in different countries of the world.

For the first time in its history, the Ministry of Foreign Affairs of Ukraine established the Office of Public Diplomacy (December, 2015) with a special unit for cultural diplomacy. This was an important step in strengthening Ukraine's strategic communications capabilities ${ }^{27}$. At the same time, experts say that full implementation of measures in this area requires additional state's attention to this issue, including the creation of specific institutions of cultural diplomacy.

The report on "Cultural Diplomacy of Ukraine: State, Problems, Prospects" 28 emphasizes the key factors that significantly affect the activity of such institutions (provided that their activities have clear and clear state support, first of all financial):

1) subordination (coordination) to the foreign policy department of the state;

2) the promotion of the language and the provision of the language learning services should become one of the most important activities of such institutions;

3) relaying values - both Ukrainian and pan-European (thus becoming part of the common European cultural space);

4) compliance with the cultural needs of the host country;

5) establishing long-lasting relationships and developing productive partnerships. The activities of cultural diplomacy institutes include going beyond diplomatic activities, supporting touring activities, promoting the development of various fields of culture and arts (cinema, theatre, visual art, music, architecture and urbanism, museum work);

6) support for contemporary culture and art;

7) a network structure;

8) support for literary projects and book publishing.

Practice shows that Ukrainian culture is represented internationally by small cultural projects, and there are a small number of cultural centres

${ }^{27}$ Petrov V. V. (2016) Shchodo stanovlennia systemy stratehichnykh komunikatsii orhaniv derzhavnoi vlady $\mathrm{u}$ konteksti rozvytku vidnosyn $\mathrm{z}$ NATO [Establishing government strategic communications system in context of development relations with NATO]. Stratehichni Priorytety [Strategic priorities], vol. 41, no. 4, pp. 24-29.

28 Rozumna O. P. (2016) Kulturna dyplomatiya Ukrayiny: stan, problemy, perspektyvy: Analitychna dopovid [Cultural diplomacy of Ukraine: state, problems, prospects: Analytical report]. Kyiv: National Institute for Strategic Studies. Retrieved from: https://niss.gov.ua/sites/default/files/2016-09/kultu_dypl-26841.pdf (accessed 4 December 2020). 
created by the Ukrainians abroad. Today, the state should facilitate the establishment and support of Ukrainian cultural centres abroad, the creation of state programs for translations into Ukrainian, as well as translations of Ukrainian authors into foreign languages.

Among the positive Ukrainian practices in this direction are: the activities of cultural and information centres at diplomatic missions of Ukraine abroad (17 centres operate), cooperating with representatives of national diasporas, in particular, holding events to celebrate national events, organising performances of national collectives and representatives of contemporary variety shows, art exhibitions, presenting literary works of both classics and contemporary Ukrainian writers. However, the analysis shows that the activities of these cultural information centres are not effective; in majority cases, they are protocol measures, events to celebrate anniversary dates, etc $^{29}$.

An important role in the development of Ukrainian cultural diplomacy is played by representatives of the Ukrainian Diaspora, in particular, scientific, educational, academic, youth, religious, and cultural organisations created by them. Ukrainians abroad culturally, informatively, politically influence and contribute to the formation of a positive image of the Ukrainian state. Many Ukrainian Diaspora-based states have established Ukrainian centres that promote the development of inter-state cooperation, such as the Ukrainian National Cultural Centre (Prague) and the Ukrainian Institute in Sweden. It is also necessary to adopt the State Program for the Development of Cultural Relations with Foreign Ukrainian, which has been talked about for many years ${ }^{30}$.

The creation of Ukrainian cultural institutes has become one of the most debated in the cultural environment. On the one hand, this should be an important step towards the implementation of a state policy of cultural diplomacy, with appropriate strategy, legal norms, a system of tasks and functions. On the other hand, the emergence of another institution in the imperfect field of cultural policy is not justified. The condition for the establishment of institutes of Ukrainian cultural diplomacy is to overcome the misunderstanding of the notion of culture in the EU and in Ukraine, and to recognize it as a facilitator of social change and development.

Understanding that the future activities of such institutes should be oriented towards European practices of cultural policy and promotion of culture, one should take into account the many relevant nuances for Ukraine

${ }^{29}$ Lutsyshyn H., Honcharuk A. (2017) Osoblyvosti rozvytku kulturnoi dyplomatii Ukrainy $\mathrm{v}$ suchasnykh umovakh [Peculiarities of the development of Ukrainian cultural diplomacy in modern conditions]. Humanitarian Vision, vol. 3, no. 1, pp. 25-30.

${ }^{30}$ Ibid. 
to model its work. However, the process of creation of Ukrainian cultural institutions should be considered as an important stage of advocacy of culture, change of attitude towards it by the state and society.

Finally, the decision to set up the State Institution "Ukrainian Institute" was adopted by the Cabinet of Ministers of Ukraine on June 21, 2017. At the presentation of the Ukrainian Institute Minister of Foreign Affairs of Ukraine P. Klimkin stated that the purpose of its creation is to promote Ukraine abroad and increase trust in our country within the international intellectual and cultural environment ${ }^{31}$.

According to the Statute of the Institute, approved by the Order of the Minister of Foreign Affairs of Ukraine, the purpose of the institution's activity is ... to improve the understanding and perception of Ukraine and the Ukrainians in the world, to develop a positive image of our country abroad. The Institute has the right to establish foreign branches in accordance with the Regulation approved by the Ministry of Foreign Affairs.

On October 18, 2018 in cooperation with the Ministry of Foreign Affairs of Ukraine there was organised the first public event of the Institute - a strategic session of the Ukrainian Institute. The purpose of the event was to formulate the mission, tasks and tools of the Ukrainian Institute, to find out the current state and prospects of the development of cultural diplomacy in Ukraine. The session was attended by about one hundred leading specialists in the field of culture, representatives of the diplomatic corps, and heads of national and international institutions, public figures, and journalists.

The concept of the Institute was presented on November 12, 2018 at the first press conference of the Ukrainian Institute, which was also dedicated to the results of the previous three months, plans and priorities for 2019.

The short-term perspectives (1 year) outlined in the Concept included ${ }^{32}$ :

- a team formation, office arrangement;

- development of internal regulations;

- determination of qualitative and quantitative indicators of activity for a three-year period;

- a brand-book development;

- communication function formation of the Institute in Ukraine and abroad;

- study the perception of Ukraine among foreign audiences;

31 Petrov V. V. (2019) Kulturna dyplomatiia yak instrument protydii hibrydnym zahrozam [Cultural diplomacy in countering hybrid threats]. Visnyk Natsionalnoi akademii kerivnykh kadriv kultury i mystetstv [National Academy of Managerial Staff of Culture and Arts Herald], no. 1, pp. 186-190.

${ }^{32}$ Ibid. 
- appointment of two foreign branches heads;

- development and launching the first programs (e.g. international mobility, support for touring activities).

However, the functioning of such institutions requires specialists in cultural diplomacy, both for the state sector and for the private and public. These experts are able to fully understand the goals and objectives of cultural diplomacy, organise the work of relevant institutions, formulate their strategic policies and understand the role of cultural diplomacy in the overall strategic communications system of the state. The training of such specialists should be a priority for Ukrainian universities, training directly for the cultural field (for example, Kyiv National University of Culture and Arts, the National Academy of Managerial Staff of Culture and Arts, etc.), where this direction can be initiated and take a practical dimension. Moreover, there is a recommendation to the Ministry of Education and Science of Ukraine to initiate the creation of a single specialized cultural diplomacy course for Ukrainian educational institutions ${ }^{33}$.

Thus, the implementation of cultural diplomacy in Ukraine will lay the foundations for overall success and create an inclusive, tolerant society that values every citizen. In today's world, globalization and digital technologies are changing the ways in which the state and the citizen interact, with direct exchanges in the field of culture playing an increasing role. Moreover, it depends only on the efforts of all Ukrainian society whether we will use this cultural potential for the benefit of our country's development and for the active and effective promotion of Ukraine's interests in the world.

A request for a cultural diplomacy policy has already been formed. In the near future, it is important to bring together all the initiatives in a single focal point to produce a document that reflects the principles of cultural diplomacy. Therefore, the success of the strategic development of the cultural sector depends directly on the adoption at the legislative level of the Concept of Humanitarian Development of Ukraine for the period up to 2030 and the Concept of the New Cultural Policy of Ukraine. Moreover, the latter should become essentially a national strategic program for the modernization of culture, which should not only give a new impetus to the spiritual life of society, but also become one of the incentives for economic development. It should be innovative in terms of the solutions proposed and flexible in terms

33 Rozumna O. P. (2016) Kulturna dyplomatiya Ukrayiny: stan, problemy, perspektyvy: Analitychna dopovid [Cultural diplomacy of Ukraine: state, problems, prospects: Analytical report]. Kyiv: National Institute for Strategic Studies. Retrieved from: https://niss.gov.ua/sites/default/files/2016-09/kultu_dypl-26841.pdf (accessed 4 December 2020). 
of the choice of forms and priorities of the state support for the cultural sphere. In its implementation, this program should be similar to national priority projects, but should be more systematic and multifactorial in its coverage. It is advisable to involve Ukrainian scientific centres, in particular, the Departments of Ukrainian Studies, at the largest universities in the world. They are a well-developed network of cultural institutions of Ukraine abroad.

The active cultural policy of Ukraine is not only a desirable state of public and interstate communication, but also an indispensable condition for the growth of our country's authority in the world political arena. The most important thing is respecting the principle of intercultural dialogue. Understanding cultural policy in dynamics requires justification of common cultural meanings of social activity. Only in this way interaction that cannot be avoided in the global world will occur in parallel with the processes of cultural rapprochement on the basis of mutual respect for the values of another. What happens in the individual mind must be transmitted to the sphere of interstate relations; personal friendly relations should become the basis of interstate politics. This approach should be comprehensive and take into account the relationships at the level of the individual, group, ethnicity, state, planetary society. The situation of the hybrid war in Ukraine, which does not allow us to directly borrow European principles into our conflict-ridden state, can also make important changes. At the same time, the collective and personal aspects must shape a social and cultural context, oriented not only to the past, but also to the present, and even more to the future ${ }^{34}$.

Thus, in the context of the European integration, our country must develop a concept of a humanitarian policy, oriented towards democratic European values, being able to adequately and effectively respond to changes in the national and cultural situation related to the processes of globalization. The reform of the institutional organisation of the state is the most important key to the implementation of the strategic plan of modernization of Ukraine, its response to the corresponding challenge and threats of cultural globalization.

\section{CONCLUSIONS}

In the modern world, the problems of identity searching for individuals as well as entire ethnic groups have intensified. It is very difficult to survive in the interwoven web of globalization and anti-globalization. The daily

${ }^{34}$ Petrov V. V. (2019) Kulturna dyplomatiia yak instrument protydii hibrydnym zahrozam [Cultural diplomacy in countering hybrid threats]. Visnyk Natsionalnoi akademii kerivnykh kadriv kultury $i$ mystetstv [National Academy of Managerial Staff of Culture and Arts Herald], no. 1, pp. 186-190. 
information pressure that the average person receives on a daily basis does not allow you to orient yourself and consciously approach the choice of what the person really needs. Therefore, the study of the problem of preserving culture in the context of Ukraine's European integration aspirations is an urgent matter. Without a scientifically based strategy, we will not only become equal members of a common European home, but we will also lose our cultural face, turning into an agricultural territory with a population of several million people.

Accordingly, the support and development of national culture is the most important direction of any country's state policy, because it realizes the constitutional right of every citizen to join the cultural heritage of the nation. Culture is an integral factor in the construction of social life. However, not only because it is inherited by a person in the process of socialization and contact with other cultures, but also it shapes the political and cultural identification of its citizens. The revival of culture is an important prerequisite for the society development and the acceleration of the state building processes. The culture and civilization of a nation or state (as opposed to the savagery and barbarity of the primitive peoples) is determined by the development level of their social order, political institutions, and measured by the aggregate of achievements in the field of sciences and arts.

The place and role of any state in the modern system of international relations depends not only on political, economic, military resources, but also on its cultural and spiritual potential, cultural heritage, which can be a powerful catalyst in achieving the foreign policy goals of the states. That is why intercultural dialogue is a significant component of the development of relations between states, both bilateral and multilateral.

The state's cultural diplomacy must primarily reflect the cultural demands of society, follow current global cultural trends, promote the cultural development of society, and generate new ideas. Experience has shown that intercultural communication is a powerful means of lobbying national interests.

A certain understanding of the essence, constituents and purpose of cultural policy influences its formation and implementation at the state level. The implementation of a particular model of cultural policy has a wide impact - from the positioning of the state in the world to the overall wellbeing of its citizens. In turn, the model of cultural policy is shaped by many factors - historical background, political regime, international agreements, economic situation, technological progress, as well as an understanding of culture and its basic and priority elements. 
Therefore, one of the important and debatable issues is the definition of the model of implementation of the foreign cultural policy of the country, in which state structures and public organizations take an active part.

Diplomacy is a part of culture, and culture, in its turn, is an effective instrument of diplomacy and an effective means of fighting for the national interests of a state. As the experience of developed countries shows, cultural diplomacy through various initiatives not only promotes national interests in the world arena, but also directly influences various political, economic and social processes.

National culture is one of the tools for forming the state's image and a means of its integration into the world cultural space. Recent years have been characterised by difficulties of social, economic, and political nature, changing vectors of external cultural relations, therefore, an adequate state's response and increase of public activity in the field of international cultural cooperation is required. Increasing the number of cultural projects, programs, days of Ukrainian culture abroad, print and electronic publications, television programs justify themselves as a means of increasing the interest of the foreign public to Ukrainian culture. The role of direct links between cultural institutions and educational institutions is increasing.

Thus, paying our attention to the various strategies and declarations in the field of culture, we can say that culture structurally includes all "peaceful" instruments of implementation of domestic and foreign policy. It actually becomes an integral part of the soft power of the state. The main demarcation line between the concepts of "culture" and "soft power" is the subjectivity of their implementation: "soft power" is officially assigned to the state and international organizations, while culture pervades all levels of society - from the municipality through civic society to the world community as a whole.

\section{SUMMARY}

Today, international relations are characterised by a variety of cooperation, with culture playing an extremely important role in. There has significantly increased the cultural dialogue influence on interstate contacts, which is a decisive factor in modifying the relations of the parties and shaping the image of the country and far beyond it. Since it is widely recognized that it is through culture that a nation reveals its identity to the world, presents its heritage, so it can be argued that cultural diplomacy is a powerful instrument of cultural policy and, in turn, of international relations of the state, and therefore it is impossible to imagine interstate dialogue without participation cultural diplomacy. The experience of the EU Member States shows that today it is important to develop new areas of cultural 
dialogue and cooperation, both within the EU and internationally, for both governmental and non-governmental programs. Practice shows that the development of cultural diplomacy in the EU countries significantly increases the effectiveness of foreign policy, adds prestige to states, national governments, reduces the influence of negative stereotypes, and strengthens the state's authority. The active cultural policy of Ukraine is not only a desirable state of public and interstate communication, but also an indispensable condition for the growth of our country's authority in the world political arena. The most important thing is respecting the principle of intercultural dialogue. Understanding cultural policy in dynamics requires justification of common cultural meanings of social activity. The situation of the hybrid war in Ukraine, which does not allow us to directly borrow European principles into our conflict-ridden state, can also make important changes. At the same time, the collective and personal aspects must shape a social and cultural context, oriented not only to the past, but also to the present, and even more to the future.

\section{REFERENCES}

1. Basenko Ya. (2013) Kulturna dyplomatiia v Yevropi [Cultural diplomacy in Europe]. Eminak, no. 1-4, pp. 53-57. (in Ukrainian)

2. Dubov D., Dubova S. (2017) Polityka kulturnoi dyplomatii yak mekhanizm realizatsii stratehichnykh komunikatsii derzhavy [The policy of cultural diplomacy as a mechanism for implementing strategic communications of the state]. Naukovi pratsi Natsionalnoi biblioteky Ukrainy imeni V. I. Vernadskoho [Academic Papers of Vernadsky National Library of Ukraine], iss. 46, pp. 62-73. (in Ukrainian)

3. European Parliament (2017) Towards an EU strategy for international cultural relations (2016/2240(INI)). Retrieved from: https://www.europarl.europa.eu/doceo/document/TA-8-2017-0303_EN.html (accessed 4 December 2020).

4. Hamilton K., Langhorne R. (2010) The Practice of Diplomacy: Its Evolution, Theory and Administration. New York: Routledge.

5. Hu Yue (2011) Culture and Cultural Diplomacy: A Comparative Study of a Canadian and Chinese Case (PhD Thesis), University of Regina, Canada.

6. Institute for Cultural Diplomacy (n.d.) What is Cultural Diplomacy? What is Soft Power? Retrieved from: http://www.culturaldiplomacy.org/ index.php?en_culturaldiplomacy (accessed 4 December 2020).

7. Lutsyshyn H., Honcharuk A. (2017) Osoblyvosti rozvytku kulturnoi dyplomatii Ukrainy $\mathrm{v}$ suchasnykh umovakh [Peculiarities of the 
development of Ukrainian cultural diplomacy in modern conditions]. Humanitarian Vision, vol. 3, no. 1, pp. 25-30. (in Ukrainian)

8. Ministers of Culture of G7 (2017) Culture as an Instrument for Dialogue among Peoples: Joint Declaration of the Ministers of Culture of G7 on the Occasion of the Meeting (Florence, March 30, 2017). Retrieved from: http://www.g7.utoronto.ca/culture/culture-2017-en.html (accessed 4 December 2020).

9. Monko T. S. (2017) Mizhnarodni vidnosyny yak skladova kulturnoi polityky Ukrainy na suchasnomu etapi [International relations as a part of cultural policy of Ukraine at the present stage]. Visnyk Natsionalnoi akademii kerivnykh kadriv kultury $i$ mystetstv [National Academy of Managerial Staff of Culture and Arts Herald], no. 2, pp. 52-55. (in Ukrainian)

10. Onuch J. (2016) Kulturna dyplomatiia, abo Vmist tsukru v tsukri [Cultural diplomacy, or Sugar content in sugar]. Ukrainskyi tyzhden [Ukrainian Week], no. 16(440), p. 50. (in Ukrainian)

11. Oshytko O. (2011). Suchasni tendentsii mizhkulturnoho spivrobitnytstva u Yevropi [Current trends in intercultural cooperation in Europe]. Viche, no. 8, pp. 17-20. (in Ukrainian)

12. Pajtinka E. (2014) Cultural diplomacy in the theory and practice of contemporary international relations. Politické vedy [Political Sciences] (electronic journal), no. 4, pp. 95-108. Retrieved from: http://www.politickevedy.fpvmv.umb.sk/archiv-vydani/2014/4-2014/.

13. Petrov V. V. (2016) Shchodo stanovlennia systemy stratehichnykh komunikatsii orhaniv derzhavnoi vlady u konteksti rozvytku vidnosyn $\mathrm{z}$ NATO [Establishing government strategic communications system in context of development relations with NATO]. Stratehichni Priorytety [Strategic priorities], vol. 41, no. 4, pp. 24-29. (in Ukrainian)

14. Petrov V. V. (2019) Kulturna dyplomatiia yak instrument protydii hibrydnym zahrozam [Cultural diplomacy in countering hybrid threats]. Visnyk Natsionalnoi akademii kerivnykh kadriv kultury i mystetstv [National Academy of Managerial Staff of Culture and Arts Herald], no. 1, pp. 186-190. (in Ukrainian)

15. Rozumna O. P. (2016) Kulturna dyplomatiya Ukrayiny: stan, problemy, perspektyvy: Analitychna dopovid [Cultural diplomacy of Ukraine: state, problems, prospects: Analytical report]. Kyiv: National Institute for Strategic Studies. Retrieved from: https://niss.gov.ua/ sites/default/files/2016-09/kultu_dypl-26841.pdf (accessed 4 December 2020). (in Ukrainian)

16. Rzhevska N. F. (2018) Kulturna dyplomatiia Ukrainy: suchasnyi stan ta perspektyvy. Mizhnarodni vidnosyny. Seriia "Politychni nauky" 
[International Relations, part "Political Sciences"] (electronic journal), no. 18-19. Retrieved from: http://journals.iir.kiev.ua/index.php/pol_n/ article/view/3377/3055 (accessed 4 December 2020). (in Ukrainian)

17. Trofymenko M. V. (2017) Publichna dyplomatiia krain Tsentralnoi ta Skhidnoi Yevropy [Public diplomacy of Central and Eastern European Countries]. Visnyk Mariupolskoho derzhavnoho universytetu. Seriia: Istoriia. Politolohiia [Journal of Mariupol State Univeristy. Series: History. Political Studies], iss. 19, pp. 257-265. (in Ukrainian)

18. UNESCO (1969) Cultural Policy: A Preliminary Study. Round-table Meeting on Cultural Policies (Monte Carlo, Monaco, 1967), UNESCO.

\section{Information about the author:}

Kostyrya Inna orcid.org/0000-0003-2654-8472

Doctor of Political Sciences, Professor Kyiv National University of Culture and Arts 36, Ye. Konovaltsia St., Kyiv, 01133, Ukraine 